\title{
PENGARUH INNOVATION TERHADAP FIRM PERFORMANCE PADA UMKM MEUBELDI KABUPATEN BOJONEGORO
}

\author{
RAKA GUNTUR SALEKSA \\ Arif Firmansyah \\ Departemen Manajemen Fakultas Ekonomi dan Bisnis Universitas Airlangga
}

\begin{abstract}
Innovation is needed by SMEs to survive and thrive in business also increase performance of the firm. Previous research referred to this study that the innovation has resulted in a positive effect on the performance of the firm. While this research discusses Effect Innovation Against Firm Performance In Furniture SMEs in Bojonegoro. The population in this study amounted to 306 the number of the sample that is used as much as 175 respondents. There are two hypotheses in this research, innovation with dimensions Product Innovation, Process Innovation, Market Innovation simultaneously significant effect on the Firm Performance as the first hypothesis, and Product innovation, has dominant influence significantly to the Firm Performance for the second hypothesis. The method used for the calculation and testing of linear regression analysis premises with SPSS tool 22. This study resulted in that the dimensions of Product Innovation, Process Innovation, Market Innovation simultaneously significant effect on Firm Performance and Product innovation, has dominant influence significantly to the Firm Performance so the both of hypothesis in this study is received. For further research that examines the SMEs, can use the object of another, larger study outside the furniture business, adding a secondary data without compromising the primary data to determine the performance of the company, also with other research models based on theories that support.
\end{abstract}

Keywords: Innovation, Product Innovation, Process Innovation, Market Innovation, Firm Performance

\section{PENDAHULUAN}

Indonesia merupakan negara berkembang yang saat ini sedang mengalami perkembangan di bidang usahanya. Pada data yang disediakan Badan Pusat Statistik (BPS) menyebutkan, pelaku usaha kecil mencapai 520.220 unit, usaha menengah 39.660 unit, dan usaha besar hanya 4.370 unit. Dengan demikian, keseluruhan wirausaha berbentuk usaha formal berjumlah 564.250 unit atau 0,24 persen dari penduduk Indonesia (www.portalhr.com). Tercatat di kementrian perindustrian jumlah industri kecil dan menengah di Indonesia sebanyak 4 juta dan mampu menyerap 9,4 juta orang tenaga kerja . Sedangkan hingga saat ini yang tercatat di kementrian koperasi tercatat ada 56,7 juta unit usaha kecil dan menengah. Sumbangsih UMKM terhadap perekonomian negara juga patut 


\section{Raka Guntur Saleksa \\ Arif Firmansyah}

diperhitungkan, kontribusinya pada tahun 2011 sebesar 57,5 persen terhadap produk domestik bruto indonesia (www.kemenperin.go.id).

Di Bojonegoro sendiri jumlah pemegang SIUP juga mengalami peningkatan yaitu pada tahun 2011 sebanyak 8.908 dan meningkat pada tahun 2012 sebanyak 9.958. Hal ini dapat mengindikasi bahwa jumlah UMKM di Bojonegoro juga mengalami peningkatan (www.bpsbojonegoro.com). Dengan data diatas dapat dikatakan bahwa UMKM memiliki berbagai kelebihan bahwa, memiliki sumbangsih terhadap PDB Indonesia dan menyerap tenaga kerja dengan menciptakan lapangan pekerjaan baru. Dengan keuntungan keuntungan tersebut terbukti bahwa UMKM berperan penting sebagai penunjang perekonomian negara, apalagi dalam menghadapi persaingan pasar bebas ASEAN tahun 2015 nanti.

Menurut Porter (1980) dalam Rosli \& Sidek (2013) mengingatkan bahwa strategi diferensiasi yang kompetitif bisa menjadi indikator bagaimana sebuah bisnis bisa bertahan. Hal ini menunjukan bahwa inovasi sangat diperlukan para pelaku UMKM untuk bisa bertahan dan berkembang dalam berbisnis. Kaplan \& Waren, (2007) dalam Rosli \& Sidek (2013) juga mengatakan bahwa inovasi bukan hal yang mewah, akan tetapi merupakan hal yang perlu. Menurut Rosli \& Sidek, (2013) inovasi menjadi hal yang sangat penting dikarenakan inovasi dapat memberi dampak positif terhadap performa perusahaan. Dengan adanya inovasi maka performa perusahaan akan meningkat. Rosli \& Sidek, (2013) juga mengatakan bahwa siapa yang melakukan inovasi akan memperbaiki performa perusahaannya. Dapat dikatakan bahwa inovasi adalah salah satu penunjang performa perusahaan.

Inovasi sendiri sudah dilakukan oleh UMKM di berbagai wilayah di Indonesia. Kurang lebih 20\% UKM dalam negeri siap menghadapi persaingan pasar bebas ASEAN 2015 melalui beragam produk kreatif dan inovatif yang sudah dikembangkan sejak berapa tahun lalu (www.depkop.go.id). Besarnya presentase tersebut dikarenakan peran pemerintah yang terus menggalang pengembangan UKM demi menghadapi persaingan pasar bebas di ASEAN tahun 2015 tersebut. Selain itu peran pihak swasta juga berperan penting dalam hal ini, kerja sama antar pemerintah dan swasta dalam pembinaan UKM khususnya bisa dikatakan berhasil. Melalui payung program "Sampoerna untuk Indonesia" contohnya PT HM Sampoerna Tbk., berhasil mendorong lahirnya 3000 UKM kreatif dan inovatif setelah mereka mengikuti program pelatihan Pusat Pelatihan Kewirausahaan (PPK) Sampoerna (www.swa.co.id). Dari contoh diatas bahwa bisa dipastikan bahwa inovasi sangat dibutuhkan oleh UKM - UKM yang ada. 
Menurut Kao (1989) dalam Rosli \& Sidek (2013) inovasi mempunyai beberapa dimensi yaitu : produk, proses, pasar, faktor, dan organisasi. Pada penelitian ini akan difokus pada dimensi produk, proses, dan pasar saja. Bagaimana ketiga hal tersebut dapat mempengaruhi performa perusahaan. Inovasi produk merupakan kreasi dari produk baru dari bahan baku baru atau perkembangan produk yang sudah ada untuk mencapai kepuasan pelanggan (Langley et al,. 2005). Sementara menurut Cumming (1998) inovasi proses merupakan proses reengineering dan pengembangan operasi internal sebuah proses bisnis. Sedangkan inovasi pasar merupakan kesepakatan dari Market mix dan Market Selection dengan tujuan untuk bertemu dengan pelanggan baru (Johne, 1999). Dimensi - dimensi tersebut mewakali pengertian dari inovasi secara umum itu sendiri.

Firm performance merupakan hasil pencapaian dari bertemunya tujuan internal maupun eksternal perusahaan (Lin et al., 2008). Jadi firm performance adalah pencapaian tujuan perusahaan yang telah dicanangkan jauh-jauh hari dan telah memenuhi targettarget yang telah ditentukan. Beberapa perusahaan, seringkali, lebih menggunakan indikator finansial untuk mengukur performa perusahaanya Grant et al., (1988) dalam Rosli \& Sidek (2013). Sisanya mereka juga menggunakan profitabilitas, produktivitas, pertumbuhan, kepuasaan stakeholder, market share, dan competitive position, menurut Garrigos-Simon dan Marques ( 2004) dalam Rosli \& Sidek (2013).

Berhubungan dengan adanya kaitan antara inovasi dan firm performance seperti yang telah dibahas sebelumnya, beberapa jurnal studi empirikal pada jurnal berusaha untuk mempelajari hal tersebut, Rosli \& Sidek (2013). Pada jurnalnya beliau mengkaitkan 3 dimensi inovasi terhadap firm performance beberapa UKM yang ada di Malaysia. Tiga dimensi yang digunakan yaitu inovasi produk, proses, dan pasar.

Berdasarkan dari berbagai pemaparan diatas, penelitian ini akan mengevaluasi tentang adanya pengaruh inovasi yang diwakili oleh tiga dimensi yang telah disebutkan yaitu inovasi produk, proses, dan pasar tehadap performa perusahaan atau yang sering disebut firm performance. Penelititan akan dilakukan di Bojonegoro, karena di wilayah Indonesia sendiri menurut data wilayah Bojonegoro juga mengalami peningkatan dibidang pertumbuhan dan juga perkembangan daripada beberapa UMKM-UMKM baru.

\section{Rumusan Masalah}

1. Apakah Innovation dengan dimensi Product innovation, Process Innovation, Market Innovation berpengaruh secara positif dan signifikan terhadap Firm Performance?

2. Apakah Product Innovation mempunyai pengaruh yang dominan terhadap firm performance daripada dimensi innovation yang lain?

\section{Landasan Teori}

\section{Innovation}

Innovation merupakan pengembangan dari lahirnya sebuah ide dan menjadikan ide tersebut peluang melaui komersialisasi (Proterius et al., 2006). Menurut Flynn et al., (2003) 


\section{Raka Guntur Saleksa \\ Arif Firmansyah}

dalam jurnal Katerina et al., (2009) innovation adalah proses mengubah peluang menjadi ide dan menempatkan ide-ide ke dalam praktek yang banyak digunakan. Innovation terdiri dari unsur kreativitas, penelitian dan pengembangan proses baru, produk atau jasa baru dan kemajuan dalam hal teknologi (Lumpkin dan Dess, 2001). Kaplan \& Waren, (2007) dalam Rosli \& Sidek (2013) juga mengatakan bahwa innovation bukan hal yang mewah, akan tetapi merupakan hal yang perlu. Jadi innovation merupakan salah satu strategi kompetitif yang diperlukan agar bisa bersaing secara kompetitif dan efektif di pasar global.

\section{Firm Performance}

Menurut Rosli \& Sidek (2013) bahwa performa merupakan cermin dari sebuah perusahaan. Jika performa buruk maka perusahaan tersebut mengalami kemunduran sedangkan jika performa baik maka perusahaan sedang mengalami kemajuan. Firm performance merupakan hasil pencapaian dari bertemunya tujuan internal maupun eksternal perusahaan (Lin et al., 2008). Beberapa perusahaan, seringkali, lebih menggunakan indikator finansial untuk mengukur performa perusahaan (Grant et al., 1988). Bagaimanapun mengukur suatu performa tidak bisa hanya dengan indikator finansial saja, indikator non finansial juga merupakan hal penting dalam mengukur performa perusahaan (Rosli \& Sidek 2013). Jadi indikator yang digunakan untuk menganalisi firm performance adalah, financial : laba perusahaan, penggunaan aset, penjualan, produktivitas perusahaan, lalu non financial : kepuasan pelanggan, pertumbuhan pelanggan, kepuasan karyawan, kualitas produk, reputasi perusahaan.

\section{Pengaruh Antara Variabel Innovation dan Firm Perfomance}

Menurut Kao (1989) dalam Rosli \& Sidek (2013) innovation mempunyai beberapa dimensi yaitu : produk, proses, pasar, faktor, dan organisasi. Sementara penelitian Rosli \& Sidek (2013) hanya menyertakan tiga dimensi saja yaitu product innovation, process innovation, dan market innovation. Penelitian ini juga hanya akan berfokus pada ketiga dimensi tersebut.

\section{Product Innovation}

Product innovation adalah adanya produk serta jasa baru dalam artian lebih baik atau adanya bahan baku baru dari dari barang (Katerina et al,. 2009). Freeman (1982) dalam Alegre, Lapiedra, \& Chiva (2006), product innovation merupakan proses yang mencakup desain teknis, penelitian dan pengembangan, manufaktur, manajemen dan kegiatan komersial terlibat dalam pemasaran produk baru (atau lebih baik). Jadi product innovation merupakan produk atau jasa baru dari bahan baku baru (barang) yang biasanya digunakan untuk memenuhi kepuasan pelanggan. Jadi indikator yang digunakan untuk mengukur variabel ini adalah pengenalan produk baru, kebaruan teknologi dalam produk, dan diferensiasi produk. 


\section{Process Innovation}

Menurut Katarina et al., (2009) process innovation adalah cara-cara baru dalam memproduksi suatu barang dan jasa. Proses perlu ada dalam suatu operasi, berfungsi untuk menciptakan sebuah inovasi. Proses sering melengkapi rantai yang hilang dari tugas yang seharusnya dilakukan, mungkin proses yang sempurna seperti itu sudah ada, atau dengan cara mengganti titik-titik proses yang lemah, atau mendesain ulang proses yang ada di sekitar dengan pengetahuan yang baru (Kuratko \& Welsch 2003 : 127). Jadi process innovation merupakan berubahnya cara-cara perusahaan dalam menghasilkan produk barang maupun jasa dengan melibatkan fungsi perusahaan, termasuk desain teknis, penelitian dan pengembangan, manufaktur, manajemen dan kegiatan komersial. Jadi indikator untuk mengukur variabel ini adalah orientasi terhadap penelitian dan pengembangan, penerapan teknologi baru, dan kombinasi bahan-bahan baru dalam produksi.

\section{Market Innovation}

Market innovation berkaitan dengan peningkatan target market mix dan bagaimana dipilihnya pasar yang terbaik (Johne 1999). Innovation mungkin tidak hanya melibatkan masuknya suatu perusahaan ke pasar baru (Hurley \& Hult 1998). Akan tetapi ada innovation yang berhubungan dengan hal tersebut, yaitu market innovation. Tujuannya adalah untuk mengidentifikasi baik pasar (baru) potensial; dan lebih baik (baru) cara untuk melayani target pasar (Johne 1999). Menurut Johne (1999), market innovation adalah pemilihan market mix dan seleksi pasar dalam rangka memenuhi preferensi pembelian pelanggan. Jadi market innovation merupakan upaya perusahaan dalam melayani prefrensi taget pasar dan juga pemenuhan target pasar dengan cara peningatan target market mix dan seleksi pasar. Pentingnya market innovation untuk firm performance, meskipun terbatas, dibahas dalam beberapa literatur (Rosli \& Sidek, 2013). Sandvik (2003) dalam jurnal Rosli \& Sidek, (2013) menemukan bahwa market innovation berpengaruh positif terhadap pertumbuhan penjualan perusahaan.Menambah temuan ini, Varis dan Littunen (2010) dalam jurnal Rosli \& Sidek, (2013) menggunakan model estimasi dikonfirmasi pengaruh yang sangat signifikan antara aktivitas inovatif yang berhubungan dengan pasar dan firm performance. Jadi indikator yang digunakan untuk mengukur variabel ini adalah penerapan transaksi online, pemasaran dan promosi yang inovatif, dan kemampuan untuk menemukan pasar baru.

$\mathrm{H}_{1}$ : Innovation dengan dimensi Product innovation, Process Innovation, Market Innovation secara simultan berpengaruh secara positif dan signifikan terhadap Firm Performance.

$\mathrm{H}_{2}$ : Product innovation, mempunyai pengaruh dominan signifikan terhadap Firm Performance. 


\section{Model Analisis}

\section{Gambar 2.1}

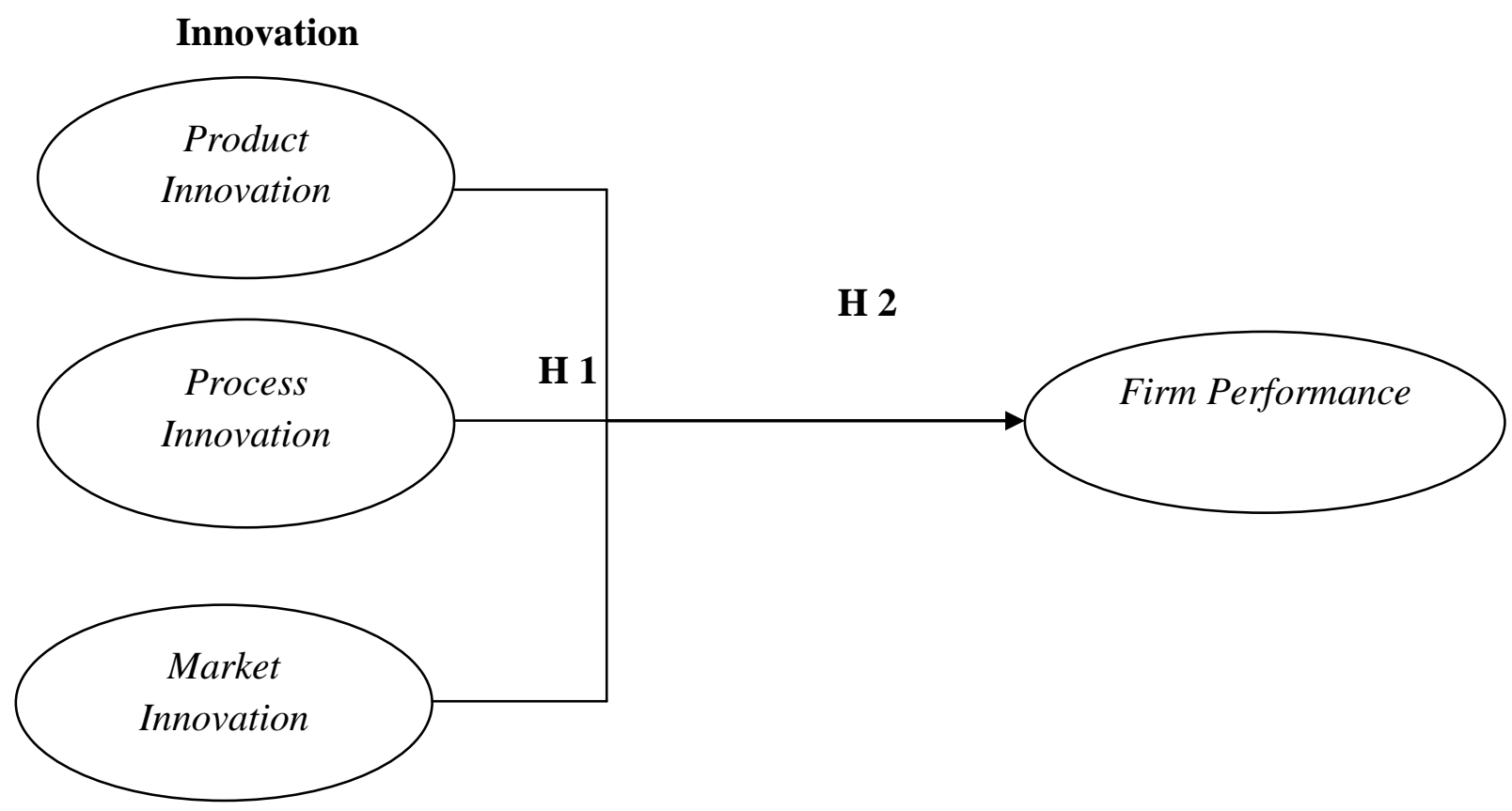

\section{Metode Penelitian}

Pendekatan dalam penelitian ini menggunakan pendekatan kuantitatif, yaitu penelitian dengan menggunakan pendekatan kuantitatif menitikberatkan dalam hal pengujian hipotesis, data yang digunakan harus terukur, dan akan menghasilkan kesimpulan yang yang dapat digeneralisasikan. Pendekatan ini dimulai dari membuat model analisis, dilanjutkan dengan membuat hipotesa, identifikasi variabel, membuat definisi operasional variabel, pengumpulan data, terakhir melakukan analisis.

\section{Definisi Operasional Variabel}

\section{Variabel Bebas X (Innovation)}

Menurut Kao (1989) dalam Rosli \& Sidek (2013) inovasi mempunyai beberapa dimensi yaitu : produk, proses, pasar, faktor, dan organisasi. Pada penelitian ini akan fokus pada dimensi produk, proses, dan pasar saja. Hal ini dikarenakan penelitian ini mengacu pada penelitian Rosli \& Sidek (2013) sendiri yang juga hanya melibatkan tiga dimensi inovasi yaitu : Product innovation $\left(X_{1.1}\right)$, Process Innovation( $\left.X_{1.2}\right)$, Market Innovation ( $X_{1.3}$ ).

A. Product innovation $\left(X_{1.1}\right)$, Inovasi produk berkaitan dengan produk atau jasa baru dari bahan baku baru (barang) yang biasanya digunakan untuk memenuhi 


\section{Jurnal Manajemen Teori dan Terapan \\ Tahun 7. No. 3, Desember 2014}

kepuasan pelanggan. Ada tiga indikator yang digunakan dalam penelitian ini terkait Product Innovation yaitu meliputi :

1. Dalam tiga tahun terakhir UKM saya menekankan penciptaan dan pengenalan produk baru,

2. Dalam tiga tahun terakhir UKM saya menekankan adanya teknologi baru dalam produk yang dihasilkan.

3. Dalam tiga tahun terakhir UKM saya menekankan adanya pembedaan produk terhadap produk pesaing.

B. Process Innovation $\left(X_{1.2}\right)$, berkaitan dengan berubahnya cara-cara perusahaan dalam menghasilkan produk barang maupun jasa dengan melibatkan fungsi perusahaan, termasuk desain teknis, penelitian dan pengembangan, manufaktur, manajemen dan kegiatan komersial. Ada tiga indikator yang digunakan dalam penelitian ini terkait Process Innovation yaitu meliputi :

1. Dalam tiga tahun terakhir UKM saya menekankan adanya pengembangan sistem produksi

2. Dalam tiga tahun terakhir UKM saya menekankan penggunaan teknologi baru dalam proses pembuatan produk, dan

3. Dalam tiga tahun terakhir UKM saya menekankan adanya kombinasi bahan-bahan baru dalam produksi

C. Market Innovation $\left(X_{1.3}\right)$, bekaitan dengan upaya perusahaan dalam melayani preferensi taget pasar dan juga pemenuhan target pasar dengan cara peningkatan target market mix dan seleksi pasar. Ada tiga indikator yang digunakan dalam penelitian ini terkait Market Innovation yaitu meliputi :

1. Dalam tiga tahu terakhir perusahaan saya menerapkan transaksi dengan menggunakan teknologi internet

2. Dalam tiga tahun terakhir perusahaan saya melakukan pemasaran yang kreatif

3. Dalam tiga tahun terakhir perusahaan saya menekankan adanya pangsa pasar baru.

Semua item tersebut diadaptasi dari penelitian Rosli \& Sidek (2013)

\section{Variabel Terikat Y (Firm Performance)}

Berkaitan dengan hasil pencapaian dari bertemunya tujuan internal maupun eksternal perusahaan, menurut Lin et al., (2008) dalam Rosli \& Sidek (2013). Beberapa indikator yang digunakan untuk mengukur Firm Performance adalah indikator finansial, profitabilitas, produktivitas, growth, kepuasaan stakeholder, market share, dan competitive position (Grant et al., 1988, Garrigos-Simon dan Marques, 2004). Ada enam indikator yang digunakan dalam penelitian ini terkait Firm Performance yaitu meliputi :

\section{Non financial performance}




\section{Raka Guntur Saleksa \\ Arif Firmansyah}

1. Bisnis yang saya kelola mampu untuk terus meningkatkan kepuasan pelanggan terhadap produk yang dihasilkan,

2. Bisnis yang saya kelola mampu mengupayakan adanya pertumbuhan pelanggan dari waktu ke waktu

3. Bisnis yang saya kelola mampu untuk terus menjaga kepuasan karyawan terhadap perusahaan,

4. Bisnis yang saya kelola mampu untuk terus menjaga dan meningkatkan kualitas produk yang dihasilkan,

5. Bisnis yang saya kelola mampu untuk terus menjaga dan meningkatkan reputasi perusahaan di mata pelanggan,

\section{Financial performance}

1. Dalam tiga tahun terakhir laba yang dihasilkan oleh perusahaan saya besar

2. Dalam tiga tahun terakhir penggunaan aset dalam menghasilkan laba di perusahaan saya maksimal

3. Dalam tiga tahun terakhir peningkatkan penjualan yang dihasilkan perusahaan saya besar

4. Dalam tiga tahun terakhir rata-rata produktivitas perusahaan saya mengalami peningkatan yang tinggi

Hal ini merupakan ukuran kinerja non-finansial dan finansial yang relevan untuk mengukur performa perusahaan. Semua item tersebut diadaptasi dari penelitian Isabel \& Elena (2006)

Prosedur pengumpulan data dilakukan dengan memberikan beberapa pertanyaan tertulis atau bisa disebut kuesioner dan diberikan untuk diisi oleh para pemilik usaha (owner) sebagai responden. Kuesioner ini bertujuan untuk mendapatkan data secara langsung dari responden. Teknik pengumpulan data yang digunakan dalam penelitian ini yaitu teknik sampel. Teknik penelitian sampel adalah teknik penelitian dengan mengumpulkan data sebagian dari populasi yang berhubungan dengan area penelitian untuk menggali informasi yang dibutuhkan (Firdaus, 2012: 29). Selain hal tersebut, pengumpulan data sekunder dilakukan dengan studi kepustakaan dari berbagai buku ataupun literatur jurnal untuk mempelajari teori-teori yang berkaitan dengan penelitian.

\section{Teknik Pengambilan Sampel}

Teknik pengambilan sampel yang digunakan dalam penelitian ini adalah metode area sampling. Menurut Firdaus (2012: 31) menyatakan bahwa area sampling adalah cara yang digunakan untuk menentukan sampel bila obyek yang akan diteliti atau sumber data sangat luas. Metode area sampling merupakan salah satu metode dalam probability sampling. Berdasarkan data Desperindag Kabupaten Bojonegoro, diketahui jumlah UMKM di bidang meubel sebanyak 306 yang tersebar di empat desa yaitu : 


\section{Jurnal Manajemen Teori dan Terapan}

Tahun 7. No. 3, Desember 2014

1. Desa Sukorejo Kecamatan Kota Bojonegoro Produksi : Furniture Jati, Interior, dan Out Door Furniture sebanyak 70 orang

2. Desa Geneng dan Desa Meduri Kecamatan Margomulyo Bojonegoro Produksi : Akar Kayu Jati, Antik Acesories, etnik Furniture sebanyak 80 orang

3. Desa Batokan, Sambeng, dan Betet Kecamatan Kasiman Bojonegoro Produksi : Bubut kayu Jati, Interior Acesories, souvenir sebanyak 136 orang

4. Desa Banaran, Kecamatan Malo Bojonegoro Produksi : Patung Kayu Binatang, Teak Wood Statue sebanyak 20 orang

Populasi dalam penelitian ini yaitu jumlah UMKM di bidang kayu dan mebel dari data Desperindag Bojonegoro. Penentuan ukuran sampel dalam penelitian ini menggunakan ukuran ketentuan Slovin. Slovin memasukkan unsur kelonggaran ketidaktelitian karena kesalahan pengambilan sampel yang masih dapat ditoleransi (Suliyanto, 2006: 100). Rumus yang digunakan sebagai berikut:

$$
n=\frac{N}{1+N \alpha^{2}} \quad 173=\frac{306}{1+306(5 \%)^{2}}
$$

Dimana:

$\mathrm{n}=$ ukuran sampel $\quad \mathrm{a}=$ toleransi ketidaktelitian (dalam persen)

$\mathrm{N}=$ ukuran populasi

Berdasarkan ukuran sampel Slovin, maka didapat jumlah sampel sebanyak 173 UMKM yang tersebar di Kabupaten Bojonegoro dengan toleransi ketidaktelitian sebesar $5 \%$.

\section{Analisis Regresi Linier}

Merupakan analisis yang digunakan untuk mengetahui pengaruh antar variabel independen dengan variabel dependen yang menggunakan persamaan linier (Priyatno, 2010:51). Jika menggunakan satu variabel independen maka disebut analisis regresi linier sederhana sedangkan jika menggunakan lebih dari satu variabel independen maka disebut analisis regresi linier berganda. Analisis ini dimaksudkan untuk meramalakan atau memprediksi suatu nilai variabel dependen dengan adanya perubahan dari variabel independen. Karena variabel di penelitian ini hanya terdapat beberapa variabel independen yang diuji secara simultan dan parsial maka menggunakan analisis regresi linier. Persamaan regresi linier adalah sebagai berikut :

$$
Y^{\prime}=b_{0}+b_{1} X+b_{2} X+b_{3} X
$$

\section{Hasil dan Pembahasan}

Berikut adalah output dari hasil analisis regresi linier yang dilakukan : 


\begin{tabular}{|c|c|c|c|c|c|c|}
\hline \multicolumn{7}{|c|}{ Coefficients ${ }^{a}$} \\
\hline \multirow{2}{*}{\multicolumn{2}{|c|}{ Model }} & \multicolumn{2}{|c|}{ Unstandardized Coefficients } & \multirow{2}{*}{$\begin{array}{c}\text { Standardized } \\
\text { Coefficients } \\
\text { Beta }\end{array}$} & \multirow[b]{2}{*}{$\mathrm{t}$} & \multirow[b]{2}{*}{ Sig. } \\
\hline & & $\mathrm{B}$ & Std. Error & & & \\
\hline \multirow[t]{4}{*}{1} & (Constant) & 23,348 & 1,498 & & 15,582 &, 000 \\
\hline & PRODUCT INNOVATION &, 358 & .172 & 209 & 2,082 &, 039 \\
\hline & PROCESSINNOVATION &, 307 &, 194 &, 163 & 1,578 &, 116 \\
\hline & MARKET INNOVATION &, 324 & 176 & 187 & 1,843 & 067 \\
\hline
\end{tabular}

a. Dependent Variable: FIRM PERFORMANCE

Model Summaryb

\begin{tabular}{|r|r|r|}
\hline $\begin{array}{c}\text { Adjusted R } \\
\text { Square }\end{array}$ & $\begin{array}{c}\text { Std. Error of } \\
\text { the Estimate }\end{array}$ & $\begin{array}{c}\text { Durbin- } \\
\text { Watson }\end{array}$ \\
\hline, 236 & 2,65766 & 2,118 \\
\hline
\end{tabular}

a. Predictors: (Constant), MARKET INNOVATION, PRODUCT INNOVATION, PROCESS INNOVATION

b. Dependent Variable: FIRM PERFORMANCE

ANOVAa

\begin{tabular}{|c|c|c|c|c|c|}
\hline Model & $\begin{array}{l}\text { Sum of } \\
\text { Squares }\end{array}$ & Df & $\begin{array}{l}\text { Mean } \\
\text { Square }\end{array}$ & $\mathrm{F}$ & Sig. \\
\hline $\begin{array}{ll}1 & \text { Regressio } \\
n\end{array}$ & 401,378 & 3 & \multirow{3}{*}{$\begin{array}{r}133,793 \\
7,063\end{array}$} & \multirow[t]{3}{*}{18,942} & \multirow[t]{3}{*}{, 000} \\
\hline Residual & 1207,802 & 171 & & & \\
\hline Total & 1609,180 & 174 & & & \\
\hline
\end{tabular}

a. Dependent Variable: FIRM PERFORMANCE

b. Predictors: (Constant), MARKET INNOVATION, PRODUCT

INNOVATION, PROCESS INNOVATION

Dilihat dari tabel uji $\dagger$ diatas maka didapatkan persamaan linier regresi berganda seperti dibawah ini :

$Y($ firm performance $)=23,335+0,358 X_{1}$ (product innovation)+ 0,307 $X_{2}$ (process innovation)+ $0,324 \mathrm{X}_{3}$ (market innovation)

Persamaan diatas memperlihatkan adanya perubahan yang searah antara variabel independen terhadap variabel dependen hal tersebut ditandai dengan koefisien regresi yang bertanda positif pada persamaan tersebut. Koefisien bertanda positif yang dimiliki oleh variabel independen tersebut dimaknai sebagai berikut :

Dimana nilai koefisien variabel independen : $X_{1}$ (Product Innovation) $0,358, X_{2}$ (Process Innovation) 0,307, dan $X_{3}$ (Market Innovation) 0,324. Hal tersebut menunjukkan bahwa ketika variabel independen $X_{1}$ (Product Innovation) meningkat sebesar satu satuan, 


\section{Jurnal Manajemen Teori dan Terapan \\ Tahun 7. No. 3, Desember 2014}

maka variabel dependen firm perfromance ( $Y$ ) akan meningkat atau positif sebesar 0,358, ketika variabel independen $X_{2}$ (Process Innovation) meningkat sebesar satu satuan, maka variabel dependen firm perfromance $(Y)$ akan meningkat atau positif sebesar 0,307, dan ketika variabel independen $X_{3}$ (Market Innovation) meningkat sebesar satu satuan, maka variabel dependen firm perfromance (Y) akan meningkat atau positif sebesar 0,324. Hal tersebut akan berlaku sebaliknya jika variabel independen mengalami penurunan.

Sedangkan jika dilihat pada tabel diatas akan diperoleh nilai konstanta sebesar 23,348 artinya jika variabel independen $X_{1}$ (Product Innovation), $X_{2}$ (Process Innovation), dan $\mathrm{X}_{3}$ (Market Innovation) nilainya adalah 0 atau dianggap konstan, maka nilai dari firm performance (Y) adalah positif sebesar 23,348.

Untuk analisis $R^{2}$ ( $R$ Square) atau koefisien determinasi yang digunakan untuk mengetahui seberapa besar prosentase sumbangan pengaruh variabel independen secara bersama-sama terhadap variabel dependen. Dilihat dari tabel output Model Summary diperoleh nilai $R^{2}$ ( $R$ square) adalah 0,249. Maka dengan hasil tersebut sumbangan pengaruh dari variabel dependen sebesar $25 \%$ dan sisanya $75 \%$ dipengaruhi variabel lain diluar penelitian.

\section{Uji F}

Untuk pengujian hipotesis pertama penelitian ini menggunakan uji F. Uji F digunakan untuk menguji ada atau tidaknya pengaruh variabel independen secara simultan terhadap variabel dependen, Jika dilihat dari tabel uji F diatas diperoleh nilai F sebesar 18,942 dengan tingkat signifikansi 0,000 . Seperti yang tertera pada ketentuan pertama bahwa nilai signifikansi uji $F \leq 0,05$ maka variabel independen $X_{1}$ (Product Innovation), $X_{2}$ (Process Innovation), dan $X_{3}$ (Market Innovation) mempunyai pengaruh positif secara simultan yang signifikan dan dapat digunakan untuk memprediksi variabel dependen $Y$ (firm performance). Jika dilihat dari perbandingan nilai F Hitung dan F Tabel, F hitung $(18,942)>F$ tabel $(2,66)$, maka hipotesis pertama penelitian ini diterima.

\section{Uji}

Uji † digunakan untuk menguji ada atau tidaknya pengaruh variabel independen secara parsial terhadap variabel dependen, selain itu dapat juga ditentukan untuk mengetahui variabel independen mana yang nilai pengaruhnya paling dominan terhadap variabel dependen. Hal ini digunakan untuk pengujian hipotesis kedua yaitu : product innovation $\left(X_{1}\right)$, mempunyai pengaruh dominan terhadap firm performance.

Dilihat dari tabel Uji $\dagger$ diatas untuk variabel product innovation diperoleh nilai $\dagger$ dari hasil perhitungan sebesar 2,082 dengan tingkat signifikansi sebesar 0,039 , process innovation diperoleh nilai † dari hasil perhitungan sebesar 1,578 dengan tingkat signifikansi sebesar 0,116, dan market innovation diperoleh nilai t dari hasil perhitungan sebesar 1,843 dengan tingkat signifikansi sebesar 0,067 . Seperti halnya ketentuan pertama dan kedua diatas maka dapat 


\section{Raka Guntur Saleksa \\ Arif Firmansyah}

disimpulkan bahwa hanya ada satu variabel independen yang signifikan dengan pengaruh positif terhadap variabel dependen firm performance $(Y)$ dan mempunyai nilai beta paling tinggi yaitu variabel product innovation $\left(X_{1}\right)$ sedangkan dua variabel lainnya yaitu $X_{2}$ (Process Innovation), dan $X_{3}$ (Market Innovation) tidak berpengaruh secara signifikan terhadap variabel dependen firm performance $(Y)$ dengan ini maka hipotesis kedua penelitian ini diterima.

\section{Simpulan}

\section{Pengaruh variabel Innovation terhadap Firm Performance}

Berdasarkan dari output pengujian yang telah dilakukan sebelumnya menunjukkan bahwa innovation dengan dimensi product innovation, process innovation, dan market innovation mempunyai pengaruh langsung secara positif dan signifikan terhadap firm performance yang diukur dengan non financial performance dan financial perfromance yang telah dicapai oleh responden yaitu UMKM meubel di Bojonegoro. Hal tersebut diketahui dari nilai uji $F$ yang mempunyai tingkat signifikansi yang nilainya $\leq 0,05$ yaitu 0,000 serta mempunyai koefisien yang positif. Koefisien positifnya didapat dari nilai $\beta$ pada tabel $t$. Maka dari itu semakin tinggi tingkat innovation yang terjadi akan meningkatkan firm performance para pengusaha UMKM meubel yang ada di Bojonegoro. Berdasarkan hal diatas menunjukkan bahwa hipotesis yang pertama yaitu Innovation dengan dimensi Product innovation, Process Innovation, Market Innovation berpengaruh secara positif dan signifikan terhadap Firm Performance diterima. Sejalan dengan penelitian sebelumnya oleh Rosli \& Sidek (2013), ditemukan bahwa Innovation dengan dimensi Product innovation, Process Innovation, Market Innovation yang dihitung secara simultan berpengaruh positif dan signifikan terhadap firm performance. Berdasarkan hal tersebut dapat disimpulkan bahwa jika para pemilik usaha mempunyai tingkat inovasi (innovation) yang tinggi, maka performa perusahaan (firm performance) juga akan meningkat tinggi searah dengan inovasinya.

Dari keterangan diatas menunjukan bahwa para pengusaha meubel di Kabupaten Bojonegoro sudah mulai sadar pentingnya inovasi (Innovation) dalam mencapai tingkat performa perusahaan (firm performance) yang tinggi. Inovasi menjadi hal yang penting karena dalam usaha meubel apalagi di daerah sentra yang kompetitif di Bojonegoro adanya inovasi merupakan pembeda dari pesaing-pesaing dari luar maupun dari dalam Kabupaten Bojonegoro itu sendiri.

Inovasi dijadikan senjata dalam menghadapi persaingan antar pemilik usaha. Apalagi dilihat dari pengamatan langsung di beberapa sentra yang ada di Bojonegoro khususnya pada sentra di Desa Sukorejo Kecamatan Kota Bojonegoro dan Desa Batokan, Sambeng, dan Betet Kecamatan Kasiman Bojonegoro Inovasi merupakan hal yang wajib 
dilakukan. Dilihat dari produknya saja setiap gerai penjualan mempunyai motif dan bentuk produk yang berbeda dari gerai lainnya.

Oleh karena itu, inovasi (innovation) memiliki pengaruh yang penting terhadap performa perusahaan (firm performance) karena dinilai sebagai alat daya saing antar perusahaan sehingga para pengusaha meubel di Kabupaten Bojonegoro performanya dari segi finansial dan non finansialnya mengalami peningkatan dan juga mampu bersaing dengan pesaing dari dalam maupun luar daerah Kabupaten.

\subsubsection{Variabel Product innovation, berpengaruh dominan terhadap Firm Performance}

Selanjutnya dilihat dari output pengujian yang juga dilakukan sebelumnya menunjukkan bahwa product innovation dibandingkan dengan process innovation, dan market innovation mempunyai pengaruh yang paling dominan dan signifikan terhadap firm performance yang diukur dengan non financial performance dan financial perfromance yang telah dicapai oleh responden yaitu UMKM meubel di Bojonegoro. Bahkan dua variabel lainya tersebut tidak berpengaruh secara signifikan terhadap firm performance.

Hal tersebut diketahui dari hasil pengujian t hitung yang digunakan untuk menguji ketiga variabel tersebut. Hasil pengujian tersebut menunjukkan hanya product innovation dengan nilai signifikansi sebesar tingkat signifikansi sebesar 0,039 yang memenuhi syarat taraf signifikansi yaitu $\leq 0,05$, variabel lainnya process innovation dengan tingkat signifikansi sebesar 0,116, dan market innovation dengan tingkat signifikansi sebesar 0,067 tidak lolos syarat signifikansi uji t. Jika dilihat dari nilai $\beta$ nya product innovation juga memiliki nilai yang paling dominan yaitu 0,358, sedangkan untuk Process Innovation $\beta=0,307$, dan Market Innovation $\beta=0,324$ berada dibawahnya.

Senada dengan penelitian sebelumnya yang juga dilakukan oleh Rosli \& Sidek (2013), pada penelitian tersebut ditemukan bahwa variabel independen product innovation memiliki pengaruh paling dominan terhadap variabel dependen firm perfromance. Bedanya pada penelitian Rosli \& Sidek tersebut dari ketiga variabel independen yaitu product innovation, process innovation dan market innovation hanya variabel market innovation yang tidak berpengaruh secara signifikan terhadap firm performance. Sedangkan pada penelitian ini ada dua variabel yang tidak berpengaruh secara signifikan terhadap firm performance yaitu process innovation dan market innovation.

Adanya perbedaan ini bisa dikarenakan demografi,jumlah, dan jenis sampel penelitian yang digunakan dalam penelitian ini berbeda dengan yang digunakan oleh Rosli \& Sidek. Penelitian sebelumnya yang dilakukan Rosli \& Sidek menggunakan sebanyak 284 sampel UMKM yang bergerak pada bidang kuliner, tekstile, dan industri berdasarkan kayu yang ada di Malaysia, sedangkan pada penelitian ini menggunakan sampel sebanyak 175 pemilik UMKM meubel yang tersebar di empat sentra meubel di Kabupaten Bojonegoro, Indonesia. 


\section{Raka Guntur Saleksa \\ Arif Firmansyah}

Keadaan nyata dilapangan menunjukan, adanya process innovation dan market innovation walaupun dengan skala besar tetap tidak menunjukkan adanya kenaikan yang signifikan pada firm performance dari UMKM meubel yang ada di Kabupaten Bojonegoro. Pengembangan sistem produksi, penggunaan teknologi baru dalam proses pembuatan produk, dan adanya kombinasi bahan-bahan baru dalam produksi tidak serta merta mempengaruhi naik turunnya performa perusahaan (firm performance). Sama halnya dengan transaksi dengan menggunakan teknologi internet, adanya pemasaran yang kreatif,dan adanya pangsa pasar baru tidak serta merta mempengaruhi naik turunnya performa perusahaan (firm performance). Sebaliknya adanya penciptaan dan pengenalan produk baru, penambahan teknologi baru dalam produk dan adanya produk yang berbeda dari produk pesaing sangat berpengaruh atas naik turunnya performa perusahaan (firm performance).

Penjelasan diatas menunjukkan bahwa para pemilik usaha meubel di Kabupaten Bojonegoro dalam meningkatakan performa perusahaannya (firm performance) sebagian besar menekankan pada inovasi produk (product innovation), dalam mengoperasikan usahanya mereka menganggap bahwa inovasi proses (process innovation) dan inovasi pasar (market innovation) bukan menjadi fokus utama.

Inovasi produk (product innovation) menjadi fokus utama dalam usaha meningkatkan performa perusahaan (firm performance) karena hasil dari inovasi tersebut langsung bisa dirasakan dan dilihat. Hal tersebut bisa dilihat dari pengamatan langsung di lapangan bahwa sebagian besar sampel yang diteliti memiliki keunikan dan perbedaan di bidang produk antara satu dengan yang lainnya. Khususnya pada sentra di Desa Sukorejo Kecamatan Kota Bojonegoro dan Desa Batokan, Sambeng, dan Betet di Kecamatan Kasiman dengan inovasi produk yang sangat beragam. Sementara pada inovasi yang lain terjadi beberapa kendala, untuk inovasi proses kendala terjadi pada adanya teknologi baru dalam proses produksi dan pengembangan sistem produksi.

Lalu untuk inovasi pasar kendalanya adalah kurangnya kesadaran akan pentingnya internet sebagai sarana promosi dan bentuk pemasaran yang kreatif pada diri masing-masing pemilik. Internet sebagian besar digunakan oleh pemilik dari sentra Desa Sukorejo Kecamatan Kota Bojonegoro dikarenakan fasilitas yang memadai, dan untuk sentra lainnya internet digunakan hanya pada skala kecil.

\section{Simpulan}

1. Innovation dengan dimensi product innovation, market innovation, dan process innovation secara simultan berpengaruh positif dan signifikan terhadap firm performance pada UMKM meubel yang ada di Kabupaten Bojonegoro. Dari hal tersebut maka dapat disimpulkan bahwa hipotesis pertama penelitian ini diterima. 
2. Product innovation mempunyai pengaruh dominan terhadap firm performance dibandingkan process innovation dan market innovation pada UMKM meubel yang ada di Kabupaten Bojonegoro. Dari hal tersebut maka dapat disimpulkan bahwa hipotesis kedua penelitian ini juga diterima.

\section{Daftar Referensi}

Alegre, Joaquín, Rafael Lapiedra, and Ricardo Chiva. 2006. A measurement scale for product innovation performance. European Journal of Innovation Management. (Vol. 9, No. 4, pp. 333-346).

Artikel. 2013. Berita : UKM Inovatif Siap Hadapi Pasar Bebas (online). (http://depkop.go.id/index.php?option=com_content\&view=article\&id=1351:ukminovatif-siap-hadapi-pasar-bebas\&catid=50:bind-berita\&itemid=97.html, diakses tanggal 19 November 2014).

Azwar, S. 1999. Metode Penelitian. Yogyakarta : Pustaka Pelajar Offset.

BPS Kabupaten Bojonegoro. 2014.

(http://bojonegorokab.bps.go.id/index.php?hal=tabel\&id=, diakses tanggal 20 November 2014).

Burhan, Bungin .2005. Metodologi Penelitian Kuantitatif : Komunikasi, Ekonomi, dan Kebijakan Publik Serta Ilmu-llmu Sosial Lainnya. Jakarta : Kencana Prenada Media Group.

Cumming, B. S. (1998). "Innovation Overview and Future Challenges," European Journal of Innovation Management, 1 (1), 21 - 29.

Firdaus, M Azis. 2012. Metode Penelitian. Edisi Pertama. Tangerang Selatan : Jelajah Nusa.

Garrigos-Simon, F. J., \& Marques, D. P. (2004). 'Competitive Strategies and Firm Performance: A Study in the Spanish Hospitality Sector,' Management Research, 2 (3), 251-269

Grant, R. M., Jammine, A. P. \& Thomas, H. (1988). "Diversity, Diversification, and Profitability among British Manufacturing Companies 1972-1984," Academy of Management Journal, $31,771-801$.

Hisrich, D.Robert. et al. 2010. Entrepreneurship. Eight Edition. United States : Mc Graw-Hill International Edition.

Hurley, Robert F., \& G. Thomas M.Hult. 1998. Innovation, Market Orientation, and Organizational Learning: An Integration and Empirical Examination. Journal of Marketin. (Vol. 62, 42-54).

Indrianto, Nur dan Bambang Supomo. 2011, "Metodologi Penelitian Bisnis Untuk Akuntansi dan Manajemen". Edisi Pertama. Yogyakarta : BPFE. 


\section{Raka Guntur Saleksa \\ Arif Firmansyah}

Johne, Axel. 1999. Successful market innovation. European Journal of Innovation Management. (Volume $2 \cdot$ Number $1 \cdot$ pp. 6-11).

Kuratko, Daniel F. \& Harold P.Welsch. 2003 : 127. Strategic entrepreneurial growth. Second edition. United States : South-Western College.

Langley, D. J., Pals, N. \& Ort, J. R. (2005). "Adoption of Behaviour: Predicting Success for Major Innovations," European Journal of Innovation Management, 8 (1), 56-78.

Lin, C.- H., Peng, C.- H., \& Kao, D. T. (2008). "The Innovativeness Effect of Market Orientation and Learning Orientation on Business Performance," International Journal of Manpower, 29 (8), 752-772.

Lumpkin, G. T \& Dess G. G. 2001. Linking two dimensions of entrepreneurial orientation to firm performance: The moderating role of environment and industry life cycle. Journal of Business Venturing. (16,429-451).

Morris, Michael H., Kuratko, \& Covin. 2007 : 199. Corporate Entrepreneurship \& Innovation. 2e Edition. United States : South-Western College.

PortalHR.com. 2010. Learning \& Development : Kurangi Pengangguran, Shell Gelar Lomba Kewirausahaan (online). (http://PortalHR.com/2010/kurangi-pengangguran-shell-gelarlomba kewirausahaan.html, diakses tanggal 19 November 2014).

Prajogo, Daniel I. Et al. 2007. Manufacturing strategies and innovation performance in newly industrialised countries. Industrial Management \& Data Systems, (Vol. 107, No. 1, pp. 52-68)

Prietto, Isabel Ma and Elena Rivera. 2006. Learning Capability and business performance: a non-financial and financial assessment. The Learning Organization. (Vol. 13 No. 2, pp. 166185).

Proterius, M. E† al. 2006. The relationship between implementation, creativity, and innovation in small business ventures. Management Dynamics, (Vol. 15, No. 1).

Rahayu, Eva Martha. 2014. Business Strategy : PPK Sampoerna Berhasil Cetak 3.000 UKM Inovatif (online). (http://swa.com/business-strategy/PPK-sampoerna-berhasil-cetak-3000ukm-inovatif.html, diakses tanggal 20 November 2014).

Rosli, M. Mohd \& Sidek, Syamsuriana (2013). The Impact of Innovation on the Performance of Small and Medium Manufacturing Enterprises: Evidence from Malaysia, Journal of Innovation Management in Small \& Medium Enterprise, IBIMA Publishing.

Saleksa, Raka Guntur dan Arif Firmansyah, 2015. Pengaruh Innovation Terhadap Firm Performance Pada UMKM Meubel di Kabupaten BOJONEGORO, 156.

Sari, Henny Rachma. 2014.Uang : Jumlah UMKM Indonesia 57,9 juta, terbanyak dibanding negara lain (online). (http://merdeka.com/uang/jumlah-umkm-indonesia-579-jutaterbanyak-dibanding-negara-lain.html, diakses tanggal 20 November 2014). 
Sarri, Katerina K. Et al. 2009. PERSPECTIVE ON PRACTICE Entrepreneur training for creativity and innovation. Journal of European Industrial Training, (Vol. 34, No. 3, pp 270-288).

Suliyanto. 2006. Metode Riset Bisnis. Yogyakarta: ANDI

Tempo. 2012. Berita Industri : Tangkal Krisis, Kadin Minta Peran UMKM Diperkuat (online).

(http://kemenperin.go.id/artikel/7684/Tangkal-Krisis,-kadin-minta-peran-UMKM-

diperkuat.html, diakses tanggal 19 November 2014).

Wiklund, Johan. 1999. The sustainability of the entrepreneurial orientation performance relationship. (37-48).

\section{Lampiran :}

Berikut adalah output dari hasil analisis regresi linier yang dilakukan :

\begin{tabular}{|c|c|c|c|c|c|c|}
\hline \multicolumn{7}{|c|}{ Coefficients ${ }^{*}$} \\
\hline \multirow{2}{*}{\multicolumn{2}{|c|}{ Model }} & \multicolumn{2}{|c|}{ Unstandardized Coefficients } & \multirow{2}{*}{$\begin{array}{c}\begin{array}{c}\text { Standardized } \\
\text { Coefficients }\end{array} \\
\text { Beta } \\
\end{array}$} & \multirow[b]{2}{*}{$\mathrm{t}$} & \multirow[b]{2}{*}{ Sig. } \\
\hline & & B & Std. Error & & & \\
\hline \multirow[t]{4}{*}{1} & (Constant) & 23,348 & 1,498 & & 15,582 &, 000 \\
\hline & PRODUCT INNOVATION &, 358 & .172 & 209 & 2,082 &, 039 \\
\hline & PROCESSINNOVATION &, 307 &, 194 & 163 & 1,578 &, 116 \\
\hline & MARKET INNOVATION & 324 & 176 & 187 & 1,843 &, 067 \\
\hline
\end{tabular}

a. Dependent Variable: FIRM PERFORMANCE

Model Summaryb

\begin{tabular}{|r|r|r|}
\hline $\begin{array}{c}\text { Adjusted R } \\
\text { Square }\end{array}$ & $\begin{array}{c}\text { Std. Error of } \\
\text { the Estimate }\end{array}$ & $\begin{array}{c}\text { Durbin- } \\
\text { Watson }\end{array}$ \\
\hline, 236 & 2,65766 & 2,118 \\
\hline
\end{tabular}

a. Predictors: (Constant), MARKET INNOVATION, PRODUCT INNOVATION, PROCESS INNOVATION 
Raka Guntur Saleksa

Arif Firmansyah

b. Dependent Variable: FIRM PERFORMANCE

ANOVAa

\begin{tabular}{|c|c|c|c|c|c|}
\hline Model & $\begin{array}{l}\text { Sum of } \\
\text { Squares }\end{array}$ & Df & $\begin{array}{l}\text { Mean } \\
\text { Square }\end{array}$ & $F$ & Sig. \\
\hline $\begin{array}{l}\text { Regressio } \\
\mathrm{n}\end{array}$ & 401,378 & 3 & 133,793 & 18,942 & ,000b \\
\hline Residual & 1207,802 & 171 & 7,063 & & \\
\hline Total & 1609,180 & 174 & & & \\
\hline
\end{tabular}

a. Dependent Variable: FIRM PERFORMANCE

b. Predictors: (Constant), MARKET INNOVATION, PRODUCT

INNOVATION, PROCESS INNOVATION 